\title{
LIFESTYLE SEGMENTATION: MOBILE PHONE PURCHASE VIS-À-VIS CONSUMPTION DECISION
}

\author{
Albert Kriestian Novi Adhi NUGRAHA (D*, Yunita Budi Rahayu SILINTOWE®, \\ Eristia Lidia PARAMITA (D) \\ Department of Management, Faculty of Economics and Business, \\ Universitas Kristen Satya Wacana, Salatiga, Indonesia
}

Received 7 October 2020; accepted 19 August 2021

\begin{abstract}
Prior studies intensively rely on lifestyle segmentation to investigate the patterns of purchase and consumption decisions. However, the literature does not specifically relate lifestyle profiles with the types of consumer decisions (i.e., purchasing vs. consumption decisions). Therefore, this research analyzed the issue by surveying 626 residents of Salatiga city, Indonesia, as the participants through self-administered questionnaires. By analyzing the data with factor, cluster, and chi-square analysis, this paper demonstrated that purchase decisions (i.e., the choice of brand name and country of origin) are not associated with lifestyle segments, while consumption decisions differ among the segments. Meanwhile, lifestyle is more likely associated with enduring (i.e., consumption decisions) than occasional behaviors (i.e., purchase decisions) such as the purchase of a mobile phone and its related services.
\end{abstract}

Keywords: lifestyle profile, factor analysis, cluster analysis, brand name, country of origin.

JEL Classification: M31.

\section{Introduction}

Marketing has shifted from mass marketing to product-based marketing to consumer target-based marketing (James et al., 2017). The latter assumes the need for market segmentation by utilizing some variables such as geographic, demographic, behavioral, and lifestyle ones (James et al., 2017). Prior studies used lifestyle to investigate consumer behavior in various purchasing settings such as food (Nie \& Zepeda, 2011; Witzling \& Shaw, 2019), fashion (Li et al., 2012), and refrigerator (Krishnan, 2011). Besides, the literature also extends the analysis to service-related consumer behavior, such as banks (Sangle \& Awasthi, 2011), electric suppliers (Sanquist et al., 2012), and tourism providers (Mahika, 2011).

Applying lifestyle as the basis for consumer segmentation is motivated by the argument that marketers need to better understand their customers before designing marketing strategies (Assael, 2005). Also, previous studies have shown that consumers with different lifestyles exhibit varying behaviors (Krishnan, 2011). Consequently, marketers need to segment the market (Sharma et al., 2020) and differentiate their strategies and tactics according to their targeted consumer segments. Lifestyle-based segmentation provides advantages of identifying consumer tendencies, values, attitudes, and behavior (Yeo et al., 2020).

An interesting outline for this research problem is smartphone purchasing decisions. A smartphone is a lifestyle-laden product (Hamka et al., 2014) because it offers a set of integrated features such as text and voice devices, video, game, and internet for various functions including communication, social network, multimedia entertainment, mobile commerce, and more (Hamka et al., 2014). Furthermore, there are more than 100 million smartphone users, which makes Indonesia the 4th largest in the world (Rahmayani, 2015). In general, $80 \%$ of the global population, both in developed and developing countries, own mobile phones (Saprikis et al., 2018).

The Digital Industry Association for Australia developed a mobile phone use index that was closely associated with consumer lifestyle profiles (Mackay \& Weidlich, 2013). These profiles include smartphone ownership, usage, the type of service provider, advertising, and marketing. Furthermore, Kim and Park (2014) extended previous studies by associating lifestyle factor with mobile phones

*Corresponding author. E-mail: albert.kriestian@uksw.edu

Copyright $\odot 2022$ The Author(s). Published by Vilnius Gediminas Technical University

This is an Open Access article distributed under the terms of the Creative Commons Attribution License (http://creativecommons.org/licenses/by/4.0/), which permits unrestricted use, distribution, and reproduction in any medium, provided the original author and source are credited. 
purchasing and usage behaviors for early adopters. Therefore, this study aimed to extend previous research, particularly Kim and Park (2014). This was achieved by focusing on the association between lifestyles and purchase decisions of mobile phones (i.e., brand name and country of origin), their associated services (i.e., mobile service provider), and consumption decision (i.e., mobile phone use).

Brand name is a sign of offers and represents consumers' expectations of product quality and risk (Zenker \& Braun, 2017). Similarly, country of origin (COO) enables consumers to summarize their beliefs about a particular product attributes or to develop a halo effect to infer the quality (Knight \& Calantone, 2000). Furthermore, brand name reflects the way consumers express their lifestyle (Çifci et al., 2016), and COO influences their evaluation through their opinions towards a country associated with a certain product (Shepard, 2016). For instance, consumers previously perceived Chinese products to be inferior (Volodzko, 2015). However, these products, such as mobile phones, have improved their quality dramatically (Shepard, 2016) and begun to dominate the Indonesian phone market (Yusuf, 2017).

Besides purchase decisions, marketers also use lifestyle-based segmentation to understand consumption patterns. In this regard, segmentation has been analyzed in various contexts both for goods (Candan \& Kapucu, 2018) and services (George-Ufot et al., 2017). However, previous studies rarely compared the ability of lifestyle factors to explain the differences in both types of consumer behavior, particularly in their product choices (i.e., brand choice) and their usage behaviour. This situation motivates the current study to fill the gap in the existing literature by empirically demonstrating the roles of lifestyle variables in segmenting both consumer actions. Hence, the objective of the article is to test the relevance of lifestyles in distinguishing market segments in the context of purchase decisions of mobile phones and associated services and mobile phone usage behaviour. Purchase and consumption are two important consumer actions for marketers because purchase generates revenue streams while consumption experience influences consumer satisfaction, leading to brand loyalty (Assael, 2005). The choice of mobile phone product is based on its position as a lifestyle product (Candan \& Kapucu, 2018), making it omnipresent.

Furthermore, the following questions were asked: "does lifestyle-based segmentation distinguish purchase and consumption decisions of mobile phones?" The effectiveness of lifestyle-based segmentation determines marketers' use of such profiles for customizing product offers to their customers. After completing data collection and analysis using a set of quantitative tools, the findings addressed the research question and hypotheses. This was followed by the discussion, the conclusion which offers theoretical and managerial implications, as well as suggestions for future research.

\section{Theoretical framework}

\subsection{Lifestyle and its typology}

Lifestyle is defined as "a mixture of habits, conventional ways of doing things, and reasoned behavior" (Nie \& Zepeda, 2011). In the psychological and sociological term, it refers to the way one exhibits unique characteristics in interacting with others that translate into lifestyle ( $\mathrm{Yu}$, 2015). Lifestyle is often used together with other terms such as "the way, quality and standard of living," "patterns of behavior," "values," and "attitudes," and even those terms are sometimes used interchangeably (Niezgoda \& Kowalska, 2020). Lifestyle is influenced by both internal factors such as demographics, beliefs, attitudes, past experiences, and personalities, as well as external factors such as social, cultural, and material (Candan \& Kapucu, 2018). Lifestyle is among the useful variables in market segmentation, considering that individuals with similarsocio-demographic profiles may express different behaviours (Díaz et al., 2018). Therefore, given the characteristic uniqueness, marketers need to appreciate lifestyle as a basis for consumer segmentation and utilize it to design strategic marketing planning for their products (Hassan et al., 2015).

Two popular measurements of lifestyle are the activities, interests, opinions (AIO) introduced by Wells and Tigert in the early 1970s, and the value, attitude, and lifestyles (VALS) introduced by Mitchell in the early 1980s that focus on US population (Yu, 2015). The AIO translates consumers' lifestyle into their activities (i.e., what they do, what they buy, and how they spend time), interests (i.e., preferences and priority), and opinions (how they view some issues in local, domestic, and global settings) (M. Kim \& C. Kim, 2020). Meanwhile, the VALS instrument covers sociodemographic profiles, personal life, which includes habits and activities, as well as perceived values which include attitudes, beliefs, hopes, prejudices, and demands (Yu, 2011). Besides the AIO and VALS lifestyle typologies, there are also others such as the Sinus-Milieu Model that divides subjects into ten groups or commonly labeled as milieus (Ernst \& Briegel, 2017), and the Euro-Socio-Styles typology that is developed in the context of European societies and divides the subjects into eight groups (Franzen \& Moriarty, 2009).

\subsection{Lifestyle and purchasing behaviors}

Previous studies related lifestyle measurement to consumer behavior (i.e., purchase and consumption behavior). For example, Kim and Park (2014) identified the mobile phone purchase and use behaviors of early adopters. In particular, they focused on the evaluation of predictive factors of purchase decisions. Similarly, other studies evaluated the role of lifestyle in explaining the adoption of mobile TV (Leung \& Chen, 2017), the purchase of refrigerator (Krishnan, 2011), food (Jang, 2017), and fashion in multi-brand stores (Choi \& Park, 2018). With its dynamic nature, brand helps consumers express themselves and 
their personal lifestyle (Adina et al., 2015). Meanwhile, consumers in emerging markets are constantly transforming their lifestyle, especially in the immerse exposure of materialism and consumerism (Siahtiri \& Lee, 2019). In this respect, the degree of brand sustainability, as measured by repeat purchases, depends on the ability to satisfy consumers' needs in achieving a particular lifestyle (Nam et al., 2011). Interestingly, few studies investigated the relationship between lifestyle and the choice of mobile phone brands, especially in the Indonesian setting. Also, mobile phone use has been a lifestyle in the country because many people spend more time using it than those from other countries (Amin, 2014).

Besides brand name, country of origin (COO) likely helps one infer quality (Adina et al., 2015). The COO refers to the country in which a particular product is made (Zeugner-Roth \& Žabkar, 2015). This arguably affects consumers choice (Fischer \& Zeugner-Roth, 2017), especially when the brands country of origin fits in the product category association (Adina et al., 2015). Meanwhile, the international marketing literature has focused on $\mathrm{COO}$ and its impact on consumer behavior (Andéhn et al., 2016), especially when producers primarily rely on export markets in selling their products. For instance, Chinese manufacturers continuously improve their product quality, which enhances acceptance from both domestic and international consumers (Shepard, 2016).

In relation to lifestyle, $\mathrm{COO}$ is directly associated with its dimensions, particularly opinions and values. For instance, consumer ethnocentrism affects the preference for domestic and foreign brands (Harcar \& Kaynak, 2015). This ethnocentrism refers to the biased preference for domestic products than for foreign (Balabanis \& Siamagka, 2017) because of the normative belief that purchasing or consuming foreign products will harm the domestic economy, reduce job opportunities for local people, and even unpatriotic (Fernández-Ferrín et al., 2018). Similar to ethnocentrism, consumer animosity is the reluctance towards foreign products due to lingering antipathy or anger towards past or ongoing political, military, economic, or diplomatic events (Klein et al., 1998). In contrast, consumers may also have positive feelings towards specific countries that they have direct personal experiences or normative exposures (Asseraf \& Shoham, 2017). Meanwhile, those from developing regions likely prefer products from developed countries because they consider these products to have higher qualities and more positive symbolic and emotional benefits (Zeugner-Roth \& Žabkar, 2015). Given these examples, COO potentially creates either positive or negative consumer evaluations that depend on the product category and the specific countries (Asseraf \& Shoham, 2017). Therefore, COO is likely associated with the particular expressions of lifestyle (i.e., opinions and values).

Based on the previous studies on the role of lifestylebased segmentation in distinguishing consumer purchase decision, the first research hypothesis was proposed as follows:
H1: Lifestyle-based segmentation distinguishes mobile phone purchase decisions.

\subsection{Lifestyle and consumption behaviors}

Lifestyle has also been used to profile consumers based on their consumption behaviors (James et al., 2017). Previous studies examined the effectiveness of lifestyle-based segmentation in distinguishing consumption behaviors for various products, such as sustainable food (Thøgersen, 2017), smartphone (Candan \& Kapucu, 2018), and industries' electric (George-Ufot et al., 2017). Interestingly, many studies focused on the relationship between lifestyle and food consumption patterns (Barrett et al., 2017; Roberts et al., 2018; Viljoen et al., 2018), although lifestyle is also used for other products, such as mobile phones (i.e., smartphones) (Candan \& Kapucu, 2018).

Currently, mobile phones, widely known as smartphones, offer various applications to their users (M.-J. Kim \& Park, 2014). The features that evolve along with the increased technology convergence enable the users to have access to broader services such as social media, information, multimedia entertainment, mobile commerce, and others (Hamka et al., 2014). Consequently, current mobile phones enable their users to participate in various activities and express their opinions by using only a single device regardless of their location. This phenomenon has drawn "scholars" attention to investigate how smartphone as an alternative platform facilitate users to carry out their daily activities such as shopping (Wang et al., 2015), banking (Yu, 2015), watching Tv (Leung \& Chen, 2017), listening to music (Sinclair \& Tinson, 2017), gaming (Balakrishnan \& Griffiths, 2018), and other activities. These examples indicate that such activities, interests, and opinions express consumers' lifestyles. Therefore, the AIO elements are likely appropriate to evaluate the conformity between lifestyle and consumer behavior (i.e., mobile purchase and consumption decision). Moreover, Yu (2011) incorporated the use of AIO elements with values as a critical element of the VALS to develop e-lifestyle measurements.

Based on the argument that lifestyle-based segmentation likely differentiates consumption decisions, the second research hypothesis was formulated as follows:

$\mathrm{H} 2$ : Lifestyle-based segmentation distinguishes mobile phone consumption decisions.

\section{Methodology}

\subsection{Data collection}

The current study used a quantitative approach to explain and generalize the patterns of mobile purchase and consumption behavior based on lifestyle segmentation. The primary data were collected through a survey that required the respondents to fill in the self-administered questionnaires. The questionnaires consisted of several question types, ranging from sociodemographic profiles 
(age, gender, and employment), purchase decision, usage behaviour, and lifestyle measurement. In this respect, the current study modified Kim and Park (2014) and Van Huy et al. (2019) to fit its purposes better. Specifically, purchase decision was measured by brand choice (Uddin et al., 2014), and usage behaviour was operationalized by extending Kim and Park (2014). Furthermore, the study borrowed and modified the lifestyle measurement that had been used in a previous study (Jadczaková, 2010). From the 80 initial items that measured lifestyle, the following modification was made. Firstly, 17 question items that were previously associated with a fashion product purchasing or consumption decisions were modified to fit the context of mobile phone. Secondly, two question items that were initially related to country of origin were adjusted with the Indonesian context. Thirdly, the double-barreled questions were broken down (see Appendix A). This study used the lifestyle measurement of Jadczaková that was developed from the Euro-Socio-Styles, VALS, Sinus Milieus, dan Experience-Milieus typologies (Jadczaková, 2010). Also, the lifestyle questions used a 5 -point Likert scale that ranges from "strongly disagree" to "strongly agree". Furthermore, the questions related to the purchasing and use of mobile phones were expressed by the responses that were measured with the nominal or categorical indicator (yes or no).

The survey period was between May-July 2018. The population for the current study was the residents of Salatiga City in Indonesia. The sample was selected using the non-probability sampling method and the purposive sampling technique based on the eligibility criteria (i.e., respondents should have mobile phone purchase and consumption experience). The survey initially drew 740 respondents. After addressing missing data and normality issues, the SPSS statistical software was used to analyze only 626 respondents. The final sample remained within the required sample size for factor analysis, ranging from

Table 1. The respondent profile

\begin{tabular}{|c|c|c|c|c|}
\hline No & Variable & Category & Frequency & $\%$ \\
\hline \multirow{2}{*}{1} & \multirow{2}{*}{ Gender } & Male & 240 & 38.3 \\
\hline & & Female & 386 & 61.7 \\
\hline \multirow{5}{*}{2} & \multirow{5}{*}{ Age } & $16-27$ & 431 & 68.9 \\
\hline & & $28-39$ & 92 & 14.7 \\
\hline & & $40-51$ & 70 & 11.2 \\
\hline & & $52-63$ & 25 & 4.0 \\
\hline & & $64-75$ & 8 & 1.3 \\
\hline \multirow{7}{*}{3} & \multirow{7}{*}{ Occupation } & Employee & 112 & 17.9 \\
\hline & & Enterpreneur & 66 & 10.5 \\
\hline & & Laborer & 15 & 2.4 \\
\hline & & Student & 367 & 58.6 \\
\hline & & Teacher & 28 & 4.5 \\
\hline & & Pensioner & 8 & 1.3 \\
\hline & & Other & 30 & 4.8 \\
\hline
\end{tabular}

three to twenty times the number of variables (i.e., 80 initial items) and absolute ranges from 100 to over 1,000 (Mundfrom et al., 2005). Subsequently, a Chi-square test was used to determine whether the sample proportion is indifferent from the population proportion. The Chisquare statistic is not significant at the $1 \%$ significance level, indicating that the sample proportion does not differ from the population proportion $\left(\chi^{2}=8.330\right.$, and $\mathrm{p}=$ 0.040).

Table 1 presents the respondents' demographic profiles, which are gender, age, and occupation. Also, most are females (61.7\%) from 16 to 27 years old (68.9\%), and students (58.6\%). Overall, the $\mathrm{Z}$ generational cohort dominated the sample proportion.

\subsection{Data analysis}

A set of factor and cluster analyses were used in this research. Such procedures were similar to what had been applied in the previous studies on lifestyle-based segmentation (Szakály et al., 2017; Weber et al., 2020). Firstly, factor analysis reduced and summarized lifestyle indicators into a smaller set that facilitates an easier interpretation. Also, it classified highly correlated indicators into the same factors, and aimed to develop several underlying ones. Secondly, cluster analysis categorized respondents into at least two unique groups based on lifestyle factors. This classified respondents with similar lifestyle profiles into the same cluster. Finally, $\chi^{2}$ analyzed whether clusters exhibited different mobile purchase and consumption behavior. This study included common method variance assessment by using Harman's single-factor test and confirmatory factor analysis (CFA) techniques (Podsakoff et al., 2003). These were used to mitigate the potential problem of common method variance of a survey in which each respondent filled in a single self-reported questionnaire at a particular time (Malhotra et al., 2006). Meanwhile, Harman's single factor test included all measurement items into exploratory factor analysis (EFA) and tested the unrotated solution. The common method of variance existed when EFA produced only a factor, or explained most of the variance of covariance between measurement items $(>50 \%)$. Furthermore, confirmatory factor analysis (CFA) was the alternative of implementing Harman's single factor test by testing the model fit of the CFA (i.e., the method factor) that consisted of all measurement items. Therefore, a good model fit of the method factor indicated the common variance problem (Malhotra et al., 2006).

\section{Result and discussion}

\subsection{Lifestyle factor formation}

The lifestyle factor formation was conducted to summarize and reduce numerous interrelated indicators into several underlying factors that are easier to be interpreted. Therefore, this current study applied the analysis by using SPSS software to analyze available datasets. Initially, 80 items were examined for their factorability. After nine 
Table 2. Factor analysis for lifestyle items

\begin{tabular}{|c|c|c|c|c|c|}
\hline Code & Item & $\begin{array}{l}\text { Need to } \\
\text { show off }\end{array}$ & $\begin{array}{c}\text { Search } \\
\text { for new } \\
\text { experience }\end{array}$ & $\begin{array}{l}\text { Family- } \\
\text { oriented } \\
\text { person }\end{array}$ & $\begin{array}{c}\text { Search for } \\
\text { an attractive } \\
\text { look }\end{array}$ \\
\hline SH1 & I prefer brand products. & 0.668 & & & \\
\hline SH3 & I prefer buying foreign products. & 0.682 & & & \\
\hline SH18 & I buy top-quality products only. & 0.790 & & & \\
\hline SH19 & I usually like quite expensive goods. & 0.785 & & & \\
\hline ED1 & I live to enjoy my life. & & & 0.568 & \\
\hline ED3 & My major life objective is to take care of my family. & & & 0.687 & \\
\hline LT1 & $\begin{array}{l}\text { It is important for me to spend my free time with my } \\
\text { children. }\end{array}$ & & & 0.786 & \\
\hline LT2 & $\begin{array}{l}\text { In my free time, it is important for me to do something } \\
\text { useful. }\end{array}$ & & & 0.712 & \\
\hline LT3 & In my free time, it is important for me to have fun. & & 0.728 & & \\
\hline LT4 & In my free time, it is important for me to meet new people. & & 0.802 & & \\
\hline LT5 & In my free time, it is important for me to find new places. & & 0.803 & & \\
\hline SH4 & $\begin{array}{l}\text { The attractive looks are the most important features of } \\
\text { products. }\end{array}$ & & & & 0.843 \\
\hline SH5 & Nice wrapping is the most important features of products. & & & & 0.870 \\
\hline
\end{tabular}

iterations, the analysis generated a structure consisting of 10 factors, with a total of 27 indicators. Subsequently, the Kaiser-Meyer-Olkin measure of sampling adequacy was .713 , which is in the middling category, while the Bartlett's test of sphericity was significant $\left(\chi^{2}(351)=2,953.77, \mathrm{p}<\right.$ $.05)$. In addition, the diagonals of the anti-image correlation matrix were all above .5 , and the communalities were all above .4.

However, not all factors met the minimum requirement of the reliability of Cronbach's alpha at 0.6. The analysis was then re-conducted only for four factors that met the minimum requirement (see Table 3 ). The final structure consisted of four factors, and they were labeled to reflect their associated indicators, namely the need to show-off, family-oriented person, search for new experience, and search for an attractive look (see Table 2). The final structure generated the Kaiser-Meyer-Olkin measure of sampling adequacy of .727, and Bartlett's test of sphericity was significant $\left(\chi^{2}(78)=1,772.45, \mathrm{p}<.05\right)$.

Table 3. Reliability analysis

\begin{tabular}{|c|l|c|}
\hline No & \multicolumn{1}{|c|}{ Lifestyle factor } & Cronbach $\alpha$ \\
\hline 1 & Need to show off & 0.735 \\
\hline 2 & Family-orientation & 0.650 \\
\hline 3 & Search for new experience & 0.722 \\
\hline 4 & Search for an attractive look & 0.722 \\
\hline
\end{tabular}

Subsequently, the common method bias was evaluated by using Harman's single-factor test and confirmatory factor analysis (CFA) techniques. The Harman's test relied on exploratory analysis and indicated a single factor that explained most of the covariance between measurement items (22.96\%). Meanwhile, further confirmatory factor analysis indicated that the result of fit measures for a single factor of CFA model was unsatisfactory; $\chi^{2}(65)=$ $1,036.981$, CFI $=0.431$, TLI $=0.318$, and $\mathrm{RMSEA}=0.155$. In fact, the results of both tests showed that common method variance was not the common source that contributed to the variance of measurement items. After the completion of factor analysis and common method variance test, the study then generated the lifestyle-based segments by running the cluster analysis.

\subsection{Cluster or segment formation}

The cluster analysis was conducted to classify respondents based on the lifestyle factors formed by the analysis. The following are the detailed procedures of the cluster analysis. Firstly, each corresponding indicator score was averaged to generate the factor scores that were then standardized using Z-scores. This was done to avoid the potential sensitivity issue due to the different scales or magnitudes among the variables (Hair et al., 2010). Secondly, the study processed the assigned indicators from the factor analysis to evaluate the similarity or dissimilarity of data objects by applying the partitioning algorithms method through the use of the k-means cluster technique. Basically, this technique calculated the Euclidean distances to relative positions of respondents within a cluster, including the distance between clusters.

The pre-selected numbers of clusters were 2 to 4 solutions and evaluated for their optimality. Meanwhile, this current study set up 20 iterations as a maximum cut-off to justify the stability of cluster formation. The analysis showed that the two-cluster solution was better than others due to the change in centers stopping at $17^{\text {th }}$ iterations 


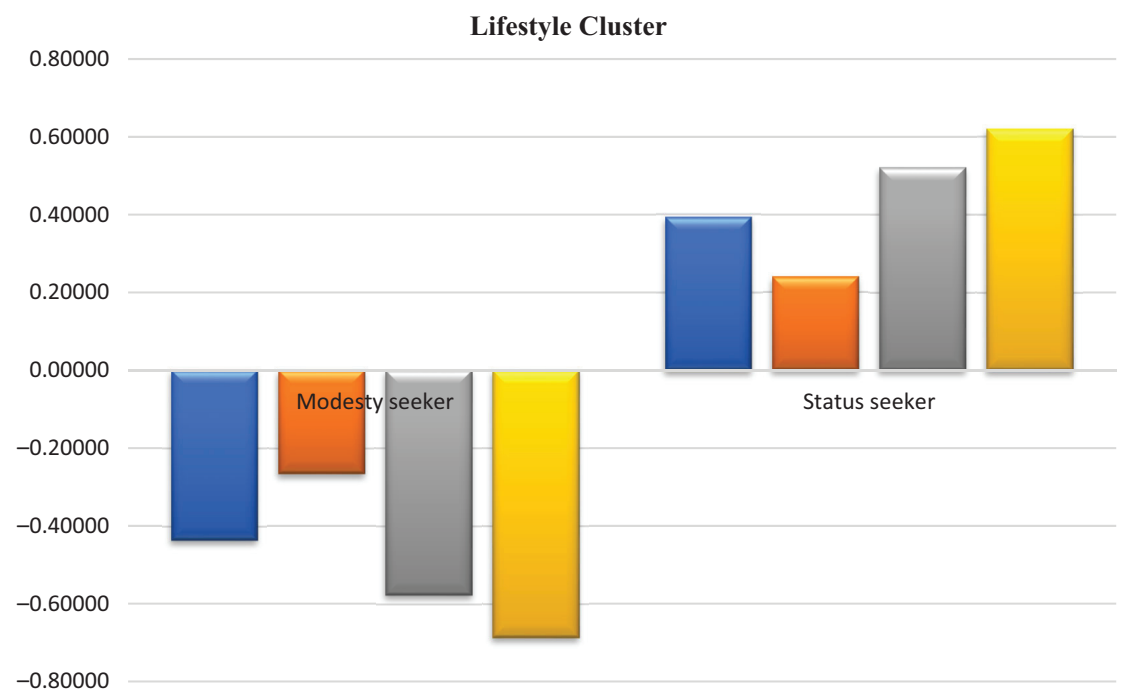

$\square$ Need to show-off $\square$ Family-oriented person $\square$ Search for new experience $\square$ Search for attractive look

Figure 1. Final cluster centers

while not for other solutions (i.e., $18^{\text {th }}$ and $19^{\text {th }}$ iterations for three and four clusters respectively). Therefore, this current study used the two-cluster solution for further analysis (see Figure 1). Meanwhile, all four lifestyle factors were able to identify significantly each cluster that all factors produced significant F-values. Finally, the study labeled each cluster based on the nature of lifestyle characteristics. Specifically, they were labeled as modesty and status seeker respectively.

\subsection{Mobile phone and mobile service purchase}

This section analyses the purchase of mobile phones and their related services (i.e., mobile service provider). Two variables measured this, which are brand name and information on country of origin (COO), while the purchase of mobile services was measured by the choices of the providers and payment types. The current study showed no association between lifestyle profile and mobile phone purchase based on brand name and $\mathrm{COO}$ of product. Meanwhile, Table 4 showed that Samsung from South Korea was the main choice of the respondents in the two segments (32.59\%), followed by Xiaomi (19.49\%), Oppo (11.82\%), Asus (9.74\%), and Apple (7.99\%). Also, Samsung dominated the respondents' mobile phone choice. Although in general, they mostly used Chinese smartphones (41.05\%), followed by South Korean mobile phones (33.07\%), Taiwanese (9.9\%), and US (8.15\%). In addition, four brands, namely Xiaomi, Oppo, Lenovo, and Vivo, mainly contributed to the popularity of Chinese phones among the respondents.

Respondents always purchased smartphones together with service providers. Table 5 showed no association between the two types of lifestyle clusters and the choice of mobile service providers, as well as its type of payment. More specifically, most respondents in both clusters $(27.80 \%)$ chose Telkomsel as their mobile service
Table 4. Brand choice and country of origin of mobile phone based on the lifestyle segment

\begin{tabular}{|c|c|c|c|c|c|}
\hline Item & $\begin{array}{l}\text { Modesty } \\
\text { Seeker }\end{array}$ & $\begin{array}{l}\text { Status } \\
\text { seeker }\end{array}$ & Total & $\begin{array}{l}\% \text { of } \\
\text { total }\end{array}$ & $\begin{array}{c}\chi^{2} \\
(\mathrm{p} \\
\text { value })\end{array}$ \\
\hline \multicolumn{6}{|c|}{ Brand choice } \\
\hline Samsung & 97 & 107 & 204 & 32.59 & \multirow{12}{*}{$\begin{array}{r}21.527 \\
(.714)\end{array}$} \\
\hline Xiaomi & 59 & 63 & 122 & 19.49 & \\
\hline Oppo & 31 & 43 & 74 & 11.82 & \\
\hline Asus & 30 & 31 & 61 & 9.74 & \\
\hline Apple & 20 & 30 & 50 & 7.99 & \\
\hline Lenovo & 15 & 20 & 35 & 5.59 & \\
\hline Vivo & 8 & 9 & 17 & 2.72 & \\
\hline Nokia & 11 & 5 & 16 & 2.56 & \\
\hline Advan & 6 & 3 & 9 & 1.44 & \\
\hline Smartfren & 5 & 3 & 8 & 1.28 & \\
\hline Sony & 3 & 3 & 6 & 0.96 & \\
\hline Others & 12 & 12 & 24 & 3.83 & \\
\hline Total & 297 & 329 & 626 & 100 & \\
\hline \multicolumn{6}{|c|}{ Country of origin } \\
\hline China & 118 & 139 & 257 & 41.05 & \multirow{8}{*}{$\begin{array}{l}9.542 \\
(.389)\end{array}$} \\
\hline South Korea & 98 & 109 & 207 & 33.07 & \\
\hline Taiwan & 31 & 31 & 62 & 9.90 & \\
\hline USA & 20 & 31 & 51 & 8.15 & \\
\hline Indonesia & 14 & 9 & 23 & 3.67 & \\
\hline Finland & 11 & 5 & 16 & 2.56 & \\
\hline Japan & 4 & 3 & 7 & 1.12 & \\
\hline Others & 1 & 2 & 3 & 0.48 & \\
\hline Total & 297 & 329 & 626 & 100.00 & \\
\hline
\end{tabular}


providers, followed by Indosat (24.92), and Tri (22.04\%). Meanwhile, the majority from both clusters preferred prepaid scheme $(80.03 \%)$ to the post-paid method. Overall, the pattern of service providers purchase was similar to mobile phone.

Table 5. The choice and type of payment of mobile service provider

\begin{tabular}{|c|c|c|c|c|c|}
\hline Item & $\begin{array}{l}\text { Modesty } \\
\text { seeker }\end{array}$ & $\begin{array}{l}\text { Status } \\
\text { seeker }\end{array}$ & Total & $\begin{array}{c}\% \text { of the } \\
\text { total }\end{array}$ & $\begin{array}{c}\chi^{2} \\
\text { (p-value) }\end{array}$ \\
\hline \multicolumn{6}{|c|}{ Mobil service provider } \\
\hline Telkomsel & 80 & 94 & 174 & 27.80 & \multirow{6}{*}{$\begin{array}{l}4.801 \\
(.570)\end{array}$} \\
\hline Indosat & 75 & 81 & 156 & 24.92 & \\
\hline Tri & 58 & 80 & 138 & 22.04 & \\
\hline Axis & 41 & 36 & 77 & 12.30 & \\
\hline XL Axiata & 36 & 32 & 68 & 10.86 & \\
\hline Others & 7 & 6 & 13 & 2.08 & \\
\hline Total & 297 & 329 & 626 & 100.00 & \\
\hline \multicolumn{6}{|c|}{ Type of mobile service payment } \\
\hline Prepaid & 242 & 259 & 501 & 80.03 & \multirow{2}{*}{$\begin{array}{c}.743 \\
(.389)\end{array}$} \\
\hline Post-paid & 55 & 70 & 125 & 19.97 & \\
\hline Total & 297 & 329 & 626 & 100.00 & \\
\hline
\end{tabular}

\subsection{Mobile usage behavior}

The extent of mobile phone use was measured with various activities that make use of available features. Table 6 showed the comparison of use based on lifestyle segment which covers various activities such as communication, information search, entertainment, online shopping, reading and editing document, mobile banking, and social media.

In general, Table 6 indicated that lifestyle profiles distinguished the use of mobile phones. Meanwhile, status seekers made use of phones more than modesty seekers for texting via WhatsApp, SMS, and e-mail while both segments do not differ in terms of voice-based communication use (i.e., phone call). Regarding information, the status seekers search for more information than modesty, such as location maps, restaurants, film, weather, infotainment, and traffic. Furthermore, status seekers searched for information about finance, health, and Tv program more frequently, although these activities constituted only a small proportion of total information search. Interestingly, although news searching was the most frequent information-searching activity for both lifestyle segments, status seekers had a slightly higher proportion than modesty.

Also, they are more likely to use their mobile phones for accessing entertainment than modesty seekers. Table 6 showed a high proportion of respondents use their mobile devices for entertainment such as games, music downloads, video downloads, and streaming. However, both lifestyle segments do not frequently use it for Tv and radio streaming. Furthermore, status seekers read and edit documents through their phones more frequently than modesty.
Table 6. The mobile phone usage

\begin{tabular}{|c|c|c|c|c|}
\hline Mobile Use & $\begin{array}{l}\text { Modesty } \\
\text { seeker }\end{array}$ & Status seeker & $\chi^{2}$ & Sig. \\
\hline Phone call & $263(88.9 \%)$ & $289(87.8 \%)$ & 0.076 & 0.783 \\
\hline Texting & $280(94.3 \%)$ & $319(97.0 \%)$ & 2.725 & $0.099^{* *}$ \\
\hline \multicolumn{5}{|c|}{ Information } \\
\hline a. News & $231(77.8 \%)$ & $274(83.3 \%)$ & 3.034 & $0.082^{\star *}$ \\
\hline $\begin{array}{l}\text { b. Infotain- } \\
\text { ment }\end{array}$ & $116(39.1 \%)$ & $166(50.5 \%)$ & 8.193 & $0.004^{\star}$ \\
\hline c. Sport & $87(29.3 \%)$ & $106(32.3 \%)$ & 0.668 & 0.414 \\
\hline d. Weather & $47(15.8 \%)$ & $85(25.8 \%)$ & 9.401 & $0.002^{\star}$ \\
\hline $\begin{array}{l}\text { e. Location } \\
\text { map }\end{array}$ & $138(46.5 \%)$ & $208(63.2 \%)$ & 17.730 & $<.001^{\star}$ \\
\hline f. Traffic & $43(14.5 \%)$ & $68(20.7 \%)$ & 4.101 & $0.043^{\star}$ \\
\hline g. Film & $144(48.6 \%)$ & $208(63.2 \%)$ & 13.452 & $<.001^{\star}$ \\
\hline h. Restaurant & $69(23.2 \%)$ & $122(37.1 \%)$ & 14.122 & $<.001^{\star}$ \\
\hline $\begin{array}{l}\text { i. TV } \\
\text { program. }\end{array}$ & $30(10.1 \%)$ & 49 (14.9\%) & 3.251 & $0.071^{\star *}$ \\
\hline j. Financial & $42(14.1 \%)$ & $74(22.5 \%)$ & 7.211 & $0.007^{\star}$ \\
\hline k. Health & $88(29.6 \%)$ & $120(36.5 \%)$ & 3.296 & $0.069^{* *}$ \\
\hline E-mail & $168(56.6 \%)$ & $230(69.9 \%)$ & 12.001 & $0.001^{\star}$ \\
\hline \multicolumn{5}{|c|}{ Entertainment } \\
\hline a. Games & $158(53.4 \%)$ & $223(67.8 \%)$ & 13.581 & $<.001^{\star}$ \\
\hline $\begin{array}{l}\text { b. Music } \\
\text { download }\end{array}$ & $133(44.9 \%)$ & $185(56.2 \%)$ & 7.959 & $0.005^{\star}$ \\
\hline $\begin{array}{l}\text { c. Music } \\
\text { streaming }\end{array}$ & $118(39.7 \%)$ & $159(48.3 \%)$ & 4.677 & $0.031^{\star}$ \\
\hline $\begin{array}{l}\text { d. Radio } \\
\text { streaming }\end{array}$ & $33(11.1 \%)$ & 35 (10.6\%) & 0.036 & 0.849 \\
\hline $\begin{array}{l}\text { e. Video } \\
\text { download }\end{array}$ & $112(37.7 \%)$ & $159(48.3 \%)$ & 7.168 & $0.007^{\star}$ \\
\hline f. Mobile TV. & $39(13.1 \%)$ & $50(15.2 \%)$ & 0.546 & 0.460 \\
\hline Online shop & $141(47.5 \%)$ & $211(64.1 \%)$ & 17.601 & $<.001^{\star}$ \\
\hline $\begin{array}{l}\text { Read and Edit } \\
\text { document }\end{array}$ & $97(32.7 \%)$ & $138(42.9 \%)$ & 5.740 & $0.017^{\star}$ \\
\hline $\begin{array}{l}\text { Mobile } \\
\text { banking }\end{array}$ & $71(24.0 \%)$ & $112(34.0 \%)$ & 7.609 & $0.006^{*}$ \\
\hline \multicolumn{5}{|c|}{ Social media } \\
\hline a. Facebook & $174(58.6 \%)$ & $213(64.7 \%)$ & 2.506 & 0.113 \\
\hline b. Twitter & $65(21.9 \%)$ & $90(27.4 \%)$ & 2.507 & 0.113 \\
\hline c. Instagram & $187(63.0 \%)$ & $269(81.8 \%)$ & 27.889 & $<.001^{\star}$ \\
\hline d. Path & $32(10.8 \%)$ & $37(11.2 \%)$ & 0.035 & 0.851 \\
\hline e. LinkedIn & $18(6.1 \%)$ & $26(7.9 \%)$ & 0.811 & 0.368 \\
\hline f. Snapchat & $31(10.4 \%)$ & $55(16.7 \%)$ & 5.194 & $0.023^{*}$ \\
\hline $\begin{array}{l}\text { Total } \\
\text { respondent }\end{array}$ & $297(100 \%)$ & 329 (100\%) & & \\
\hline
\end{tabular}

Note: ${ }^{\star}$ significant at $\mathrm{p}<0.05 ;{ }^{*}$ significant at $\mathrm{p}<0.10$.

Besides information search and entertainment, smartphones are also used for online shopping, banking, and interaction via social media. Table 6 showed that status seekers are more likely to use their smartphones for these activities. Meanwhile, in terms of social interaction, 
Instagram, Facebook, and Twitter are the three most frequently used platforms, especially for status seekers. A small proportion of the respondents from both lifestyle segments use other social media platforms such as Snapchat, Path, and LinkedIn, with both lifestyle segments exhibiting similar use of these platforms except for Snapchat.

\section{Discussions}

The results showed that lifestyle was more relevant to explain the differences in consumption decisions than in purchase. This consisted of activities, interests, and opinions that are generally attached to individuals' daily activities. Moreover, respondents' use of mobile phones depended on how they reflected their lifestyle into the use. For instance, status seekers are arguably family-oriented persons, exhibit a higher need to show off, and tend to search for attractive looks. In contrast, modesty seekers avoid show-off, enjoy daily routines, are family-oriented persons, and prefer regular looks.

Product purchase decisions of mobile phones and their associated services (i.e., telecommunication providers) are not related to lifestyle factors. Also, the results are likely affected by the fact that all mobile phone brands offer similar features to meet their users' needs to express various activities, interests, and opinions. In addition, most brands offered various product types with different price levels from low-cost to high-end for both modesty and status seekers. Brand name and country of origin preferences that are associated with mobile phone purchases do not differ among both segments. Meanwhile, Samsung, the South Korean mobile phone, was the most dominant brand choice for each segment. However, some Chinese device brands such as Xiaomi and Oppo began to overtake Samsung and position their prominent market share in the global market. This situation indicated that the competitiveness of these products dramatically increases in the global market (Shepard, 2016).

The decision to choose service providers shows a similar pattern to choose mobile phones. In particular, the proportion of each service provider did not differ between both segments. Therefore, lifestyle-based segmentation could not identify provider preferences, likely because each basically offered similar services, such as phone-call, texting, and internet connection for information search, e-mail, entertainment, and more. Therefore, respondents' preference for service provider was likely affected by brand image, the quality of internet connection, and price. Interestingly, both status and modesty seekers preferred prepaid to post-paid payment schemes, possibly because the prepaid type offers lower fixed cost commitment and more flexibility to users.

Furthermore, other results demonstrated that status seekers engage in information search more than modesty. In fact, they are interested in searching for new experiences (e.g., visiting new culinary spots, recommended tourism destinations, or watching new movies in cinemas) and making use of mobile phones to search for information about location maps, restaurants, film, weather, and traffic. They also likely involve others, such as family members in their activities and share such experiences with others through social media, particularly Instagram and Facebook. Such platforms enable status seekers to post their new experiences in text, pictures, and videos that eventually facilitate their desires to show off.

Status seekers translate their needs for having an attractive look through shopping online. For instance, they are more likely to use smartphones to buy attractive goods (e.g., outfits, accessories) and pay the transactions online. They arguably buy attractive goods to show off to others. Besides aiming to have higher social status by engaging in new experiences and having luxurious or branded goods, status seekers amuse themselves by accessing film information, infotainment, and other entertainments such as games, music, and videos.

Subsequently, the proportion of mobile phone use to access social media varied among lifestyle segments. In particular, the results depended on the platform characteristics, which include maturity, popularity, and service involvement. For instance, Facebook and Twitter have been very popular since its inception in 2004 and 2006 respectively (McFadden, 2018). Therefore, these platforms have been at the maturity stage, and all respondents considered these media as generic for both segments. Similar results were also found for the less popular platform such as LinkedIn, probably because it focuses on developing professional networks and is not directly associated with lifestyle factors.

Meanwhile, Instagram was the most popular platform, especially for status seekers. It has been the most frequently used social media and a more recent platform compared to Facebook and Twitter (i.e., it was launched in 2010) (McFadden, 2018). This platform focuses on photo content to share lifestyle-associated experiences such as entertainment, fashion, beauty, food, location, and social or people (Jang et al., 2015). The findings also showed that status seekers used Snapchat more than modesty seekers, although this platform is less popular than others. The popularity of these social media is mainly because of the ability of such platforms to meet status seekers' needs to interact with new people and experiences.

\subsection{Managerial implications}

The findings revealed the following to smartphone marketers and mobile service providers. Firstly, marketers need to use non-lifestyle factors to segment their markets. Although the findings suggested that lifestyle does not identify the purchase decisions of service providers, it is arguably still important to analyze the consumption experience of mobile services based on lifestyle profiles. Also, the service providers could focus their marketing activities to status seekers because their lifestyle leads them to use mobile phones more than modesty seekers. By doing this, service providers easily expand phone usage, especially for mobile internet. In this respect, they need to provide fast 
and reliable internet connections to ensure users' positive experience. Secondly, it was suggested that service providers expand mobile phone features that fit their consumers' lifestyle characteristics. Furthermore, they need to continuously create attractive offers, especially to maintain their existing customers (i.e., status seekers). Given the significant association between consumption experience and consumer lifestyle profiles, service providers need to focus on the use of consumption situation attributes for the status seeker segment. Thirdly, in the context of marketing communication, they need to emphasize consumption situation attributes as a basis for their product advertisements. However, the higher proportion of prepaid mobile service users relative to that of post-paid poses challenges for the service providers to maintain consumer loyalty. This is because prepaid schemes offer more flexibility to search for alternative providers with lower switching costs.

\subsection{Limitations}

The current study analyzed the purchase decision of only mobile phones based on brand name (Kim \& Park, 2014), country of origin (Yunus \& Rashid, 2016) and excluded other product attributes such as price, design, quality, and features. This is because these two attributes arguably summarized others (Knight \& Calantone, 2000; Sammut-Bonnici, 2015), both for consumers who have limited knowledge or no prior experience with the products and those who already made the purchases and aimed to reduce risks or shorten decision making routes for their next purchases. Brand and country of origin are essential in the cognitive-based economy (Assael, 2005). However, the current study did not cover the cognitive elements of purchase decisions and only focused on behavioral aspects (i.e., the choice of brand name and COO). This limited the ability to explain the rationale of the decisions. Lastly, the current study does not generalize results to characterize Indonesian consumers due to its limited sample (i.e., only from one city). Therefore, future research may accommodate the need for broader sample scope.

\subsection{Research implication and further research}

These findings underscore the importance of exploring various moderating variables to explain the effectiveness of lifestyle-based segmentation in understanding various consumer profiles. Therefore, this paper advised future studies to elaborate on the role of lifestyle in identifying consumers' behavior based on the frequency of purchase and consumption, behaviors for different product categories, and also for low and high product involvement. The results arguably inform marketers in applying the lifestyle factor to understand consumption behavior better.

Future studies are also suggested to compare the use of behavioral and cognitive approaches to generate a better understanding of consumer behavior for different types of product involvement. Such studies potentially generate comprehensive insights about consumers and factors that motivate them to exhibit such behavior. Also, subsequent studies may focus on the strength of association between brand name and $\mathrm{COO}$ as summary cues for price, design, quality, and features between potential and actual customers.

\section{Conclusions}

Lifestyle factors allow lifestyle-based segmentation to better explain the differences in consumer behavior. Based on this behavior, the simple structure indicated that not all lifestyle measures should be included. In this study, four relevant lifestyle factors were indicated, which are the need to show-off, family-oriented person, search for new experience, and search for an attractive look.

Meanwhile, the lifestyle factor is more relevant to identify behavior in using mobile services than the purchase behavior of smartphones and the choice of service providers. Also, lifestyle expresses consumers' daily activities, interests, opinions, and values. Therefore, involvement in lifestyle measures could be translated into various mobile service features. In fact, consumers are more likely to use available features when their lifestyle characteristics fit better with mobile service features.

Purchasing phones and their associated services are generally occasional, while the decisions to use them are more routine. These findings imply that lifestyle fits more in routine than occasional consumer (both purchasing and consumption) behaviors. Furthermore, lifestyle-based segmentation likely explains the segment differences when consumers make frequent purchasing or consumption decisions. This argument is consistent with the definition of lifestyle that includes an element of habit (Nie \& Zepeda, 2011) which is in everyday parlance as a ....... frequent, persistent, or customary behavior "..." (Gardner, 2015).

\section{Author contributions}

Albert Kriestian Novi Adhi NUGRAHA: Ideas, creation of model, development of methodology, data analysis, data visualization, writing initial draft, and arranging English translation and proofreading.

Yunita Budi Rahayu SILINTOWE: Ideas, project administration, budget, data collection management, data analysis.

Eristia Lidia PARAMITA: Ideas, project administration, budget, data collection management.

\section{Disclosure statement}

Authors do not have any competing financial, professional, or personal interests from other parties.

\section{References}

Amin, K. (2014). Indonesians spend most time on smartphones in the world. The Jakarta Post. https://www.thejakartapost. com/news/2014/06/05/indonesians-spend-most-time-smartphones-world.html 
Andéhn, M., Nordin, F., \& Nilsson, M. (2016). Facets of country image and brand equity: Revisiting the role of product categories in country-of-origin effect research. Journal of Consumer Behaviour, 15(3), 225-238. https://doi.org/10.1002/cb.1550

Assael, H. (2005). Consumer behavior: A strategic approach. Houghton Mifflin Company.

Asseraf, Y., \& Shoham, A. (2017). Destination branding: The role of consumer affinity. Journal of Destination Marketing \& Management, 6(4), 375-384. https://doi.org/10.1016/j.jdmm.2016.06.004

Balabanis, G., \& Siamagka, N.-T. (2017). Inconsistencies in the behavioural effects of consumer ethnocentrism: The role of brand, product category and country of origin. International Marketing Review, 34(2), 166-182.

https://doi.org/10.1108/IMR-03-2015-0057

Balakrishnan, J., \& Griffiths, M. (2018). Loyalty towards online games, gaming addiction, and purchase intention towards online mobile in-game features. Computers in Human Behavior, 87, 238-246. https://doi.org/10.1016/j.chb.2018.06.002

Barrett, P., Imamura, F., Brage, S., Griffin, S. J., Wareham, N. J., \& Forouhi, N. G. (2017). Sociodemographic, lifestyle and behavioural factors associated with consumption of sweetened beverages among adults in Cambridgeshire, UK: the Fenland study. Public Health Nutrition, 20(15), 2766-2777. https://doi.org/10.1017/S136898001700177X

Candan, F. B., \& Kapucu, H. (2018). The effect of lifestyle on conspicuous consumption. In O. Ekşi \& F. B. Candan (Eds.), Current debates in business studies (Vol. 15, pp. 109-125). IJOPEC Publication Limited.

Choi, M., \& Park, K. (2018). Differences in awareness, attitude and purchase intention of multi-brand stores among fashion lifestyle groups. Journal of the Korean Society of Clothing Textiles, 42(3), 438-451.

https://doi.org/10.5850/JKSCT.2018.42.3.438

Christea, A., Capatina, G., \& Stoenescu, R.-D. (2015). Countryof-origin effects on perceived brand positioning. Procedia Economics Finance, 23, 422-427. https://doi.org/10.1016/S2212-5671(15)00383-4

Çifci, S., Ekinci, Y., Whyatt, G., Japutra, A., Molinillo, S., \& Siala, H. (2016). A cross validation of consumer-based brand equity models: Driving customer equity in retail brands. Journal of Business Research, 69(9), 3740-3747.

https://doi.org/10.1016/j.jbusres.2015.12.066

Díaz, A., Gómez, M., Molina, A., \& Santos, J. (2018). A segmentation study of cinema consumers based on values and lifestyle. Journal of Retailing and Consumer Services, 41, 79-89. https://doi.org/10.1016/j.jretconser.2017.12.001

Ernst, A., \& Briegel, R. (2017). A dynamic and spatially explicit psychological model of the diffusion of green electricity across Germany. Journal of Environmental Psychology, 52, 183-193. https://doi.org/10.1016/j.jenvp.2016.12.003

Fernández-Ferrín, P., Calvo-Turrientes, A., Bande, B., ArtarazMiñón, M., \& Galán-Ladero, M. M. (2018). The valuation and purchase of food products that combine local, regional and traditional features: The influence of consumer ethnocentrism. Food Quality and Preference, 64, 138-147. https://doi.org/10.1016/j.foodqual.2017.09.015

Fischer, P. M., \& Zeugner-Roth, K. P. (2017). Disentangling country-of-origin effects: The interplay of product ethnicity, national identity, and consumer ethnocentrism. Marketing Letters, 28(2), 189-204.

https://doi.org/10.1007/s11002-016-9400-7

Franzen, G., \& Moriarty, S. E. (2009). The science and art of branding. M.E. Sharpe, Inc.
Gardner, B. (2015). A review and analysis of the use of 'habit' in understanding, predicting and influencing health-related behaviour. Health Psychology Review, 9(3), 277-295.

https://doi.org/10.1080/17437199.2013.876238

George-Ufot, G., Qu, Y., \& Orji, I. J. (2017). Sustainable lifestyle factors influencing industries' electric consumption patterns using Fuzzy logic and DEMATEL: The Nigerian perspective. Journal of Cleaner Production, 162, 624-634. https://doi.org/10.1016/j.jclepro.2017.05.188

Hair, J. F., Tatham, R. L., Anderson, R. E., \& Black, W. (2010). Multivariate data analysis. Pearson Prentice Hall Upper Saddle River, NJ.

Hamka, F., Bouwman, H., De Reuver, M., \& Kroesen, M. (2014). Mobile customer segmentation based on smartphone measurement. Telematics and Informatics, 31(2), 220-227. https://doi.org/10.1016/j.tele.2013.08.006

Harcar, T., \& Kaynak, E. (2015). The impact of country-of-origin and ethnocentrism: An experimental study of consumer taste preferences for soft drinks at cross-cultural level. Journal of Euromarketing, 24(2-3), 120-131.

https://doi.org/10.9768/0024.02-3.120

Hassan, S. H., Ramayah, T., Mohamed, O., \& Maghsoudi, A. (2015). E-Lifestyle conceptualization: Measurement model validation using variance based structural equation modeling (SEM-PLS). Modern Applied Science, 9(2), 307-319. https://doi.org/10.5539/mas.v9n2p307

Jadczaková, V. (2010). Evaluation and analysis of questionnaire lifestyle segmentation. Department of Statistics and Operation Analysis. Mendel University.

James, A., Ravichandran, S., Chuang, N. K., \& Bolden, E. (2017). Using lifestyle analysis to develop lodging packages for staycation travelers: An exploratory study. Journal of Quality Assurance in Hospitality and Tourism, 18(4), 387-415. https://doi.org/10.1080/1528008X.2016.1250240

Jang, J.-S. (2017). The comparative study on the purchase of convenience foods according to the food-related lifestyle in Chinese students. The Korean Journal of Food Nutrition, 30(1), 105-111. https://doi.org/10.9799/ksfan.2017.30.1.105

Jang, J. Y., Han, K., Shih, P. C., \& Lee, D. (2015). Generation like: Comparative characteristics in Instagram. In Proceedings of the 33rd Annual ACM Conference on Human Factors in Computing Systems, 4039-4042.

https://doi.org/10.1145/2702123.2702555

Kim, M.-J., \& Park, J. (2014). Mobile phone purchase and usage behaviours of early adopter groups in Korea. Behaviour \& Information Technology, 33(7), 693-703.

https://doi.org/10.1080/0144929X.2013.796001

Kim, M., \& Kim, C. (2020). Lifestyle and travel motivation of the elderly in South Korea: Baseline characteristics and the relationship between demographic factors. International Journal of Hospitality \& Tourism Administration, 21(2), 141-164. https://doi.org/10.1080/15256480.2018.1464417

Klein, J. G., Ettenson, R., \& Morris, M. D. (1998). The animosity model of foreign product purchase: An empirical test in the people's Republic of China. Journal of Marketing, 62(1), 89-100. https://doi.org/10.1177/002224299806200108

Knight, G. A., \& Calantone, R. J. (2000). A flexible model of consumer country-of-origin perceptions: A cross-cultural investigation. International Marketing Review, 17(2), 127-145. https://doi.org/10.1108/02651330010322615

Krishnan, J. (2011). Lifestyle-A tool for understanding buyer behavior. International Journal of Economics and Management, 5(1), 283-298. 
Leung, L., \& Chen, C. (2017). Extending the theory of planned behavior: A study of lifestyles, contextual factors, mobile viewing habits, TV content interest, and intention to adopt mobile TV. Telematics Informatics, 34(8), 1638-1649. https://doi.org/10.1016/j.tele.2017.07.010

Li, G., Li, G., \& Kambele, Z. (2012). Luxury fashion brand consumers in China: Perceived value, fashion lifestyle, and willingness to pay. Journal of Business Research, 65(10), 15161522. https://doi.org/10.1016/j.jbusres.2011.10.019

Mackay, M. M., \& Weidlich, O. (2013). Australian mobile phone lifestyle index. AIMIA-The Digital Industry Association of Australia. http://www.sponsor-ed.com.au/app/webroot/uploaded_files/media/Ampli\%202013\%20Report_Final_October\%2024.pdf

Mahika, E.-C. (2011). Current trends in tourist motivation. Cactus Tourism Journal, 2(2), 15-24.

Malhotra, N. K., Kim, S. S., \& Patil, A. (2006). Common method variance in is research: A comparison of alternative approaches and a reanalysis of past research. Management Science, 52(12), 1865-1883. https://doi.org/10.1287/mnsc.1060.0597

McFadden, C. (2018). A chronological history of social media. Interesting Engineering. https://interestingengineering.com/achronological-history-of-social-media

Mundfrom, D. J., Shaw, D. G., \& Ke, T. L. (2005). Minimum sample size recommendations for conducting factor analyses. International Journal of Testing, 5(2), 159-168. https://doi.org/10.1207/s15327574ijt0502_4

Nam, J., Ekinci, Y., \& Whyatt, G. (2011). Brand equity, brand loyalty and consumer satisfaction. Annals of Tourism Research, 38(3), 1009-1030.

https://doi.org/10.1016/j.annals.2011.01.015

Nie, C., \& Zepeda, L. (2011). Lifestyle segmentation of US food shoppers to examine organic and local food consumption. Appetite, 57(1), 28-37.

https://doi.org/10.1016/j.appet.2011.03.012

Niezgoda, A., \& Kowalska, K. (2020). Sharing economy and lifestyle changes, as exemplified by the tourism market. Sustainability, 12(13), 5351. https://doi.org/10.3390/su12135351

Podsakoff, P. M., MacKenzie, S. B., Lee, J.-Y., \& Podsakoff, N. P. (2003). Common method biases in behavioral research: A critical review of the literature and recommended remedies. Journal of Applied Psychology, 88(5), 879.

https://doi.org/10.1037/0021-9010.88.5.879

Rahmayani, I. (2015). Indonesia raksasa teknologi digital Asia. https://www.kominfo.go.id/content/detail/6095/indonesiaraksasa-teknologi-digital-asia/0/sorotan_media

Roberts, K., Cade, J., Dawson, J., \& Holdsworth, M. (2018). Empirically derived dietary patterns in UK adults are associated with sociodemographic characteristics, lifestyle, and diet quality. Nutrients, 10(2), 1-17. https://doi.org/10.3390/nu10020177

Sammut-Bonnici, T. (2015). Brand and branding. In Wiley Encyclopedia of Management (pp. 1-3). Wiley.

https://doi.org/10.1002/9781118785317.weom120161

Sangle, P. S., \& Awasthi, P. (2011). Consumer's expectations from mobile CRM services: A banking context. Business Process Management Journal, 17(6), 898-918. https://doi.org/10.1108/14637151111182684

Sanquist, T. F., Orr, H., Shui, B., \& Bittner, A. C. (2012). Lifestyle factors in US residential electricity consumption. Energy Policy, 42, 354-364. https://doi.org/10.1016/j.enpol.2011.11.092

Saprikis, V., Markos, A., Zarmpou, T., \& Vlachopoulou, M. (2018). Mobile shopping consumers' behavior: An explorato- ry study and review. Journal of Theoretical Applied Electronic Commerce Research, 13(1), 71-90.

https://doi.org/10.4067/S0718-18762018000100105

Sharma, P., Singh, S., \& Misra, R. (2020). Wine-related lifestyle segmentation in the context of urban Indian consumers. International Journal of Wine Business Research, 32(4). https://doi.org/10.1108/IJWBR-05-2019-0036

Shepard, W. (2016). How "made in China" became cool. Forbes. https:/www.forbes.com/sites/wadeshepard/2016/05/22/howmade-in-china-became-cool/\#1 eae713f77a4

Siahtiri, V., \& Lee, W. J. (Thomas). (2019). How do materialists choose prominent brands in emerging markets? Journal of Retailing Consumer Services, 46, 133-138. https://doi.org/10.1016/j.jretconser.2017.08.021

Sinclair, G., \& Tinson, J. (2017). Psychological ownership and music streaming consumption. Journal of Business Research, 71, 1-9. https://doi.org/10.1016/j.jbusres.2016.10.002

Szakály, Z., Popp, J., Kontor, E., Kovács, S., Pető, K., \& Jasák, H. (2017). Attitudes of the lifestyle of health and sustainability segment in Hungary. Sustainability, 9(10), 1763.

https://doi.org/10.3390/su9101763

Thøgersen, J. (2017). Sustainable food consumption in the nexus between national context and private lifestyle: A multi-level study. Food Quality and Preference, 55, 16-25. https://doi.org/10.1016/j.foodqual.2016.08.006

Uddin, M. R., Lopa, N. Z., \& Oheduzzaman, M. (2014). Factors affecting customers' buying decisions of mobile phone: A study on Khulna City, Bangladesh. International Journal of Managing Value and Supply Chains, 5(2), 21-28. https://doi.org/10.5121/ijmvsc.2014.5203

Van Huy, L., Chi, M. T. T., Lobo, A., Nguyen, N., \& Long, P. H. (2019). Effective segmentation of organic food consumers in Vietnam using food-related lifestyles. Sustainability, 11(5), 1237. https://doi.org/10.3390/su11051237

Viljoen, A. T., van der Spuy, E., \& du Rand, G. E. (2018). Food consumption, lifestyle patterns, and body mass index of a group of white South African students. International Journal of Consumer Studies, 42(5), 533-546.

https://doi.org/10.1111/ijcs.12465

Volodzko, D. (2015). How "made in China" became a stigma. The Diplomat. https://thediplomat.com/2015/07/how-made-inchina-became-a-stigma/

Wang, R. J.-H., Malthouse, E. C., \& Krishnamurthi, L. (2015). On the go: How mobile shopping affects customer purchase behavior. Journal of Retailing, 91(2), 217-234. https://doi.org/10.1016/j.jretai.2015.01.002

Weber, W., Reinhardt, A., \& Rossmann, C. (2020). Lifestyle segmentation to explain the online health information-seeking behavior of older adults: Representative telephone survey. Journal of Medical Internet Research, 22(6), e15099. https://doi.org/10.2196/15099

Witzling, L., \& Shaw, B. R. (2019). Lifestyle segmentation and political ideology: Toward understanding beliefs and behavior about local food. Appetite, 132, 106-113. https://doi.org/10.1016/j.appet.2018.10.003

Yeo, G. E., Cho, M.-S., \& Oh, J. (2020). Food-related lifestyle segmentation and beverage attribute' selection: Toward understanding of sugar-reduced beverages choice. British Food Journal, 122(12), 3663-3677. https://doi.org/10.1108/BFJ-10-2019-0817

Yu, C.-S. (2011). Construction and validation of an e-lifestyle instrument. Internet Research, 21(3), 214-235. https://doi.org/10.1108/10662241111139282 
Yu, C.-S. (2015). Using e-lifestyle to analyze mobile banking adopters and non-adopters. Journal of Global Information Technology Management, 18(3), 188-213.

https://doi.org/10.1080/1097198X.2015.1070619

Yunus, N. S. N. M., \& Rashid, W. E. W. (2016). The influence of country-of-origin on consumer purchase intention: The mobile phones brand from China. Procedia Economics Finance, 37, 343-349. https://doi.org/10.1016/S2212-5671(16)30135-6

Yusuf, O. (2017). Daftar 5 besar merek smartphone di Indonesia. Kompas.Com.

http://tekno.kompas.com/read/2017/11/23/08410067/daftar5-besar-merek-smartphone-di-indonesia

Zenker, S., \& Braun, E. (2017). Questioning a "one size fits all" city brand: Developing a branded house strategy for place brand management. Journal of Place Management Development, 10(3), 270-287.

https://doi.org/10.1108/JPMD-04-2016-0018

Zeugner-Roth, K. P., \& Žabkar, V. (2015). Bridging the gap between country and destination image: Assessing common facets and their predictive validity. Journal of Business Research, 68(9), 1844-1853.

https://doi.org/10.1016/j.jbusres.2015.01.012 